\section{Rapid, Nonradioactive Screening for Activating ras Oncogene Mutations Using PCR-primer Introduced Restriction Analysis (PCR-PIRA)}

\section{Daniel R. Jacobson and Tibor Moskovits}

Research Service 151-C, New York Veterans Administration Medical Center and NYU Medical Center, New York, New York 10010
None of the mutations in codons 12 , 13 , or 61 of the K-ras, N-ras, and H-ras genes, which convert them into active oncogenes, ${ }^{(1)}$ creates or destroys a new restriction site for any known enzyme. A method based on the introduction of an artificial restriction site into a $\mathrm{PCR}$ product by the use of a primer containing a single-base mismatch at the $3^{\prime}$ end has been used to detect a point mutation in codon 12 of K-ras. ${ }^{(2)} \mathrm{We}$ have expanded this strategy to develop a simple screening system for activating ras mutations, termed PCR-primer introduced restriction analysis (PCRPIRA).

\section{METHODS}

DNA was isolated from cells containing known ras mutations, obtained from the American Type Culture Collection [HT 1080 (heterozygous $\mathrm{N}$-ras codon $61 \mathrm{CAA} \rightarrow \mathrm{AAA}$ ), SW 480 (homozygous K-ras codon 12 GGT $\rightarrow$ GTT), MOLT-4 (heterozygous $\mathrm{N}$-ras codon 12 GGT $\rightarrow$ TGT], (3) from lymphoid tissue from a patient with $\gamma$-immunoglobulin heavy-chain disease (HCD), and from normal controls. Genomic DNA, 0.125 $\mu \mathrm{g}$, was PCR-amplified $\left(94^{\circ} \mathrm{C} \times 45 \mathrm{sec}\right.$, $55^{\circ} \mathrm{C} \times 45 \mathrm{sec} \times 30$ cycles $^{(4)}$ across Kand $\mathrm{N}$-ras codons 12,13 , and 61 using previously described primers. ${ }^{(5)}$ Secondary PCR was then performed on 1 $\mu l$ of a 1:1000 dilution of the initial PCR product, using the same 3 ' primer as well as a nested $5^{\prime}$ primer, which contained a one- or two-base mismatch with the original PCR product and introduced a new restriction site into the second PCR product, such that a mutation in the codon being tested led to the loss of the new site (Table 1). In the secondary PCR, annealing was performed at $50^{\circ} \mathrm{C}$ to allow uniform primer binding despite the mismatches. Secondary PCR products were digested with the appropriate endonucleases and electrophoresed on $12 \%$ acrylamide (Fig. 1) or $2.5 \%$ agarose (Figs. 2 and 3 ) gels containing ethidium bromide. This protocol yielded complete digestion of the normal sequence, partial digestion with one normal and one mutated allele, or no digestion in the absence of a normal allele.

\section{RESULTS}

Each two-step PCR yielded a product of the expected length which was cut by the appropriate restriction enzyme in the absence of a mutation, demonstrating the validity of the method (Figs. 1-3). The primer pairs used in the secondary PCR could also be used to amplify genomic DNA directly, but the two-step method produced higher, more specific yields.

A typical heterozygous mutation is seen for N-ras codon 12, in which the secondary PCR product of $92 \mathrm{bp}$ derived from the normal sequence was digested into products of 73 and $19 \mathrm{bp}$ by MspI. A mutation in position 1 or 2 of the codon should destroy the MspI site, leading to a digestion-resistant product. As predicted, a $G \rightarrow$ I transversion at position 1 of the codon led to incomplete MspI digestion (Fig. 1). Similarly, for $\mathrm{N}$-ras codon 61 , the secondary PCR product derived from normal DNA was entirely digested by $\mathrm{Mscl}$, whereas HT $1080 \mathrm{DNA}$, containing a heterozygous position $1 \mathrm{C} \rightarrow \mathrm{A}$ transversion, yielded two bands (not shown). DNA from the patient with HCD showed the same patterns as HT 1080 DNA (not shown). A homozygous mutation is shown in K-ras codon 12, where the normal secondary product was completely digested, and a homozygous position $2 \mathrm{G} \rightarrow \mathrm{T}$ transversion rendered the PCR product resistant to digestion (Fig. 2). The K-ras 12 test consistently demonstrated the most resistance to digestion, and required the greatest excess of endonuclease; why this was so, particularly in comparison to the similar, easily digested N-ras test, is unclear. Because of this difficulty, an alternative strategy for this codon has also been developed, using a doubly mismatched primer and $B s a / l$ (D.R. Jacobson and N.E. Mills, unpublished). PCR products were also obtained using the other seven screening primers listed in Table $1, \mathrm{~A}$ and $\mathrm{B}$, and were completely digested by the appropriate restriction enzymes, indicating successful creation of restriction sites (Fig. 3 for KS61S and NS61S, others not shown).

\section{DISCUSSION}

We have overcome the fact that no activating ras mutation changes a restriction site by using PCR primers containing one- or two-base mismatches from the target sequence to create artificial 
TABLE 1A Screening PCR Primers and Restriction Sites Formed

\begin{tabular}{|c|c|c|c|}
\hline Codon & Name & $\begin{array}{l}\text { Screening Primers and } \\
\text { estriction Sites Created } \\
\text { DNA Sequence }\end{array}$ & $\begin{array}{l}\text { Restriction } \\
\text { enzyme }\end{array}$ \\
\hline K-Ras 12 & $\mathrm{KS} 12$ & 5 'AACTTGTGGTAGTTGGAGCEggt... & Msp I \\
\hline N-Ras 12 & NS 12 & 5'AACTGGTGGTGGTTGGAGCGggt... & Msp I \\
\hline $\mathrm{K}$-Ras 13 & KS 13 & 5 TTGTGGTAGTTCCAGCTGGTggc... & Pflm I \\
\hline $\mathrm{N}$-Ras 13 & NS13 & 5. TGGTGGTGGTTCCAGCAGGTggt... & Pf $1 \mathrm{~m} \mathrm{I}$ \\
\hline $\begin{array}{l}\text { K-Ras } 61 \\
(\mathrm{CA}-)\end{array}$ & KS61 & 5.ATATTCTCGACACAGCTEATCaA... & Bcl I \\
\hline $\begin{array}{l}\text { N-Ras } 61 \\
(\mathrm{CA}-)\end{array}$ & NS61 & 5. ACATACTGGatacaGCTGGCcaa... & Msc I \\
\hline $\begin{array}{c}\text { K-Ras } 61 \\
(--\mathrm{A})\end{array}$ & KS61S & $\begin{array}{r}596061 \\
/ / / / / / \\
\text { 5'ATTCTCGACACAGCAGGTIAa... }\end{array}$ & Mse I \\
\hline $\begin{array}{l}\text { N-Ras } 61 \\
(--A)\end{array}$ & NS61S & $\begin{array}{r}596061 \\
/ / / / / \\
\text { 5 'ATACTGGATACAGCTGGTAa... }\end{array}$ & Mse I \\
\hline
\end{tabular}

TABLE 1B PCR Primers Used to Determine Whether Mutations at the Codon 61 Position 3 Are Activating $(A \rightarrow C$ or $A \rightarrow T)$ or Silent $(A \rightarrow G)$

\begin{tabular}{|c|c|c|c|}
\hline \multirow[t]{2}{*}{ Codon } & \multicolumn{2}{|r|}{$\begin{array}{l}\text { Screening Primers and } \\
\text { Restriction Sites Created }\end{array}$} & \multirow[t]{2}{*}{$\begin{array}{l}\text { Restriction } \\
\text { enzyme }\end{array}$} \\
\hline & Name & DNA Sequence & \\
\hline $\begin{array}{l}\text { K-Ras } 61 \\
(--G)\end{array}$ & $\mathrm{KS} 61 \mathrm{G}$ & 5 'CTCATTGCACTGTACAGCTCctg... & Alwn I \\
\hline $\begin{array}{l}\text { N-Ras } 61 \\
(--G)\end{array}$ & NS61G & 5 ' CTCATGGCACTGTACAGTTCCtg... & Alwn I \\
\hline
\end{tabular}

sites. During PCR, the same substitutions are introduced into both normal and mutated sequences, but restriction sites are formed only in PCR products derived from normal alleles. This strategy was used to demonstrate activating mutations in $\mathrm{N}$-ras codons 12 and 61 and in K-ras codon 12 , and the absence of other activating ras mutations in the samples tested. For codons 12 and 13 , a mutation in position 1 or 2 eliminates the artificial restriction site for Mspl (codon 12) or Pflm I (codon 13). Codon 61 screening is performed in two steps because $\mathrm{CAA} \rightarrow \mathrm{CAC}$ and $\mathrm{CAA} \rightarrow \mathrm{CAT}$ mutations are not silent, and no enzyme can readily test all three positions. To

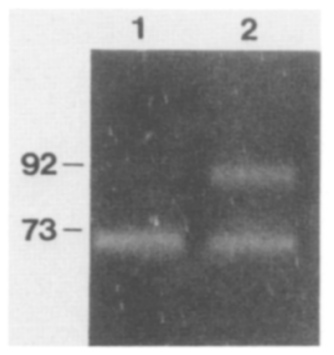

FIGURE 1 PCR products amplified using screening primer NS12, MspI-digested. (Lane 1) Control DNA; (lane 2) Molt 4 DNA. Sizes are in base pairs.

$3^{\prime}$ mismatches have previously yielded products visible on agarose gels, when the mismatched bases retained one purine and one pyrimidine; other mismatches were more destabilizing. ${ }^{(2,6)}$ Similarly, we used primers containing single mismatches in the 3 ' base to screen for mutations in $\mathrm{N}$-ras codons 12 and 61 and $\mathrm{K}$-ras codon 12, and in the penultimate base to screen position 3 of K-ras codon 61 . Because of the sequences around the other codons of interest, strategies using single mismatched primers were not available. We reasoned that a screening primer containing two mismatches might work in PCR, particularly if the mismatches were not near the 3 ' base. In four cases (KS13, NS13, KS61G, and NS61G), the two mismatches were three or more bases from the 3 ' end. The other two screening primers containing double mismatches (KS61 and NS61S) contained mismatches closer to their 3 ' ends; primer NS61S, which we predicted would be most likely to fail in the PCR, created mismatches between two pyrimidines at both the penultimate and antepenultimate bases; nonetheless, this primer pro-

screen positions 1 and 2, a site ending in CA was created for $B c l l$ (K-ras) or MscI (N-ras). This step demonstrated the $\mathrm{N}$-ras codon 61 mutation in $\mathrm{HT}$ 1080 DNA and revealed a mutation in DNA derived from a patient with HCD, suggesting that ras activation plays a role in HCD. To screen codon 61 position 3, artificial Msel restriction sites are created. This method detects any mutation in position 3 of codon 61 , including the silent transition $A \rightarrow G$. The primers in Table $1 \mathrm{~B}$ are used to distinguish between a silent and activating mutation; the nested ( $\left.3^{\prime}\right)$ primer is used in the secondary $\mathrm{PCR}$ with the original 5 ' primer.

PCR primers containing single-base

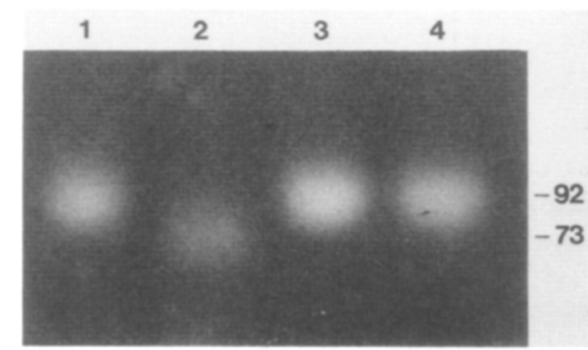

FIGURE 2 PCR products amplified using screening primer KS12, MspI-digested. (Lane 1) Undigested control DNA; (lane 2) MspIdigested control DNA; (lane 3): undigested SW 480 DNA; (lane 4) Mspl-digested SW 480 DNA. 


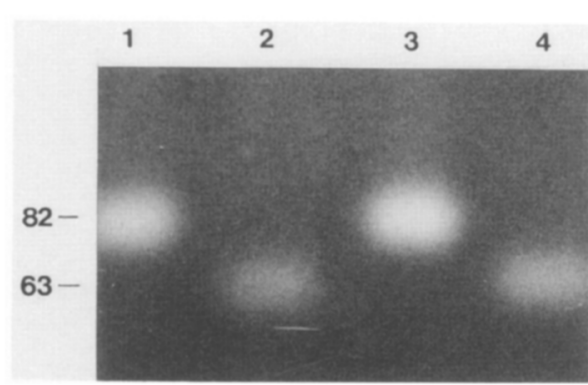

FICURE 3 PCR products amplified from control DNA using the screening primer NS61S (lanes 1 and 2) or KS61S (lanes 3 and 4), before (lanes 1 and 3) and after (lanes 2 and 4) Msel digestion.

vided high yields (Fig. 3), suggesting that the matched 3 ' base counteracted the adjacent mismatches.

Recently, activating ras mutations have been most often detected by allele-specific oligonucleotide (ASO) hybridization, ${ }^{(7)}$ which requires one labeled oligonucleotide for each possible mutation -40 in all. In the PCRPIRA method, because each screening primer creates a restriction site in the presence of the normal sequence, each one tests simultaneously for three or six possible mutations; thus, only 10 screening primers are required (although the PCR-PIRA method does not completely define the mutation present). PCR-PIRA is adaptable to the analysis of most point mutations in any gene when no naturally occurring restriction site is present. We demonstrate the feasibility of using primers with two-base mismatches, which makes this method more powerful than if one uses only single-mismatch primers. PCR-PIRA is simple and nonradioactive, and should facilitate the analysis of mutations in ras genes and throughout the genome.

\section{ACKNOWLEDGMENTS}

We thank Joel Buxbaum for support. This work was supported by the Department of Veterans Affairs and National Institutes of Health National Research Service Award T32HL07151.

\section{REFERENCES}

1. Bos, J.L. 1989. RAS oncogene in human cancer: A review. Cancer Res. 49: 4682-4689.

2. Haliassos, A., J.C. Chomel, J. Kruh, J.C. Kaplan, and A. Kitzis. 1989. Detection of minority point muta- tions by modified PCR technique: A new approach for a sensitive diagnosis of tumor-progression markers. Nucleic Acids Res. 17: 8093-8099.

3. Verlaan-de Vries, M., M.E. Bogaard, H. van den Elst, J.H. Van Boom, A.J. van der Eb, and J.L. Bos. 1986. A dot blot screening procedure for mutated ras oncogenes using synthetic oligodeoxynucleotides. Gene 50: 313-320.

4. Jacobson, D.R., P.D. Gorevic, and J.N. Buxbaum. 1990. A homozygous transthyretin variant associated with senile systemic amyloidosis: Evidence for a late-onset disease of genetic etiology. Am. I. Hum. Genet. 47: 127-136.

5. Neri, A., D.M. Knowles, A. Greco, F. McCormick, and R. Dalla-Favera. 1988. Analysis of RAS oncogene mutations in human lymphoid malignancies. Proc. Natl. Acad. Sci. 85: 9268-9272.

6. Newton, C.R., A. Graham, L.E. Heptinstall, S.J. Powell, C. Summers, N. Kaisheker, J.C. Smith, and A.F. Markham. 1989. Analysis of any point mutation in DNA. The amplification refractory mutation system (ARMS). Nucleic Acids Res. 17: 2503-2516.

7. Kazazian H.H. 1989. Use of PCR in the diagnosis of monogenic disease. In PCR technology: Principles and application for DNA amplification (ed. H.A. Erlich), pp. 153-169. Stockton Press, New York.

Received June 19, 1991; accepted in revised form September 9, 1991. 